\title{
Developmental studies on leafy spurge (Euphorbia esula): Histochemical and autoradiographic studies of the adventitious shoot apices
}

\author{
M. V. S. RAJU and TERESA W. M. HO \\ The authors are with the Biology Department, University of Saskatchewan, Regina, Saskatchewan, Canada.
}

(Editor's Note: Figures in this article were taken from photocopies. Consequently, they are not of the same quality as the original. However, they still illustrate pertinent information and so are included here.)

\begin{abstract}
:
Analysis of apices at four different developmental stages (progressively older from I to IV) of adventitious shoots of leafy spurge (Euphorbia esula L.) was carried out. In this study, some selected histochemical and autoradiographic techniques were used to study DNA, histone, and RNA changes during vegetative shoot growth. In the early vegetative phases (stages I to III), the DNA distribution and DNA synthesis based on Feulgen stain and thymidine- $\mathrm{H}^{3}$ incorporation respectively were found to be greater in the peripheral sectors $\left(\mathrm{S}_{1}\right.$ and $\left.\mathrm{S}_{3}\right)$ than in the midsector $\left(\mathrm{S}_{2}\right)$ and consequently the apex showed a characteristic cytozonation. The central zone $\left(\mathrm{S}_{2}\right)$ showed less DNA staining and the rate of DNA synthesis was slower than that in the peripheral sectors. This central zone, which is often considered as méristème d'attente, cannot be interpreted similarly for there was slow DNA synthesis as indicated by the low incorporation of thymidine- $\mathrm{H}^{3}$. It is suggested that the nuclei in $\mathrm{S}_{2}$ in stages II and III had a longer mitotic cycle than those in $\mathrm{S}_{1}$ and $\mathrm{S}_{3}$. The zonal pattern seen in the early stages disappeared in stage IV. This final stage may be considered as the "intermediate phase" during the transformation of the vegetative apex to the floral apex. The distribution of nucleohistones based on results of alkaline fastgreen staining procedure was similar to that of Feulgen stain for DNA at all four stages. However, when lysine groups in the histone were blocked by acetylation method, the apices showed that the argininerich histone fraction was dominant and uniform in all four stages. This means that in stages II and III, $\mathrm{S}_{2}$ had less lysine-rich histone fraction than $\mathrm{S}_{1}$ and $\mathrm{S}_{3}$. The nuclei in $\mathrm{S}_{2}$ in stages II and III had longer mitotic cycle and
\end{abstract}


this was probably due to less lysine-rich histone content. The cytoplasmic RNA observed by following pyronin Y - methyl green staining method and RNA synthesis based on uridine- $\mathrm{H}^{3}$ incorporation showed no sharp differences among the three sectors of the apex in all four developmental stages. It is interpreted, therefore, that the central zone $\left(\mathrm{S}_{2}\right)$ in the apex was, although slow, quite active metabolically during the development of the adventitious shoot.

\section{Introduction}

It has been demonstrated by a variety of histochemical and histoautoradiographic techniques that the shoot apices of higher vascular plants contain a cytozonation in which the most distal axial cells correspond to Buvat's méristème d'attente (Gifford 1954; Gifford and Corson 1971). Many Franco-Belgian investigators have described and discussed the méristème d'attente in relation to the transformation of vegetative shoot-apex to floral state (Buvat 1952, 1953; Lance 1952, 1953a, 1953b, 1954, 1957; Nougarède and Bronchart 1965; Nougarède 1967; Bernier 1970; Gifford and Corson 1971). This méristème d'attente has been interpreted to have no histogenic or organogenic role during vegetative growth and its cells remain in a state of mitotic inactivity; however, the same group of cells is reported to have a significant role in the change from vegetative to reproductive state (Buvat 1952, 1953).

In a recent article, Steeves et al. (1969) have made a critical assessment of the méristème d'attente concept on the basis of their analytical studies on the shoot apex of Helianthus annuus. They have demonstrated in the vegetative apex an unmistakable central region corresponding to méristème d'attente in which there was little or no mitotic activity and DNA synthesis was reduced to a very slow rate. Since most of the information of the above type has been obtained from highly selected or cultivated species, they have strongly warned that more species belonging to diverse growth habits should be investigated to warrant generalization of the occurrence of méristème d'attente in higher vascular plants.

Euphorbia esula L. is a vigorous, persistent weed in the prairies (Raju et al. 1963, 1964). The seedling produces an extensive root system which basically consists of long and short roots. The long roots produce adventitious buds which in spring and summer develop into flowering shoots. However, similar adventitious shoots in the greenhouse do not generally flower. In earlier reports (Raju 1968; Ho 1970) it has been shown that more cells in mitosis were found in the peripheral sectors of the apices than in the central region. It was also observed that the apices of buds during their development into adult shoots showed certain histological changes. The apices of older shoots tended to have a greater number of mantle layers than the buds and younger shoots. Cytological analyses showed that in the midsector the nuclei and nucleoli were larger than in the peripheral sectors; the nuclei in the former had fewer nucleoli. The total volume of nucleoli per nucleus was found to be more in the midsector than in the peripheral sectors and this suggests the possible presence of a cytozonation. The ratio of total nucleolar volume to nuclear volume was about the same in all the sectors of the apex. On this basis it was

Page 2 of 17 
concluded that the metabolic activity in the apex was uniform at all stages of development of adventitious buds to adult shoots (Ho and Raju 1972). To follow up these earlier investigations and to obtain more information, apices of buds and shoots of leafy spurge were subjected to a few selected histochemical and histoautoradiographic tests. Results dealing with DNA, histone, and RNA changes at different developmental stages of adventitious buds and shoots are presented and discussed in this paper in relation to the behavior of the vegetative shoot apex. A need for a similar study has recently been emphasized that "no approach should be made to this and similar problems of causation connected with flowering without consideration of the detailed behaviour of the shoot apex during the whole course of its development" (Heslop-Harrison and Heslop-Harrison 1970).

\section{Materials and methods}

In the present study, apices of adventitious buds and shoots of Euphorbia esula L. were collected from plants raised in the greenhouse. The buds and shoots were categorized into four developmental stages, I to IV, according to their lengths. Stage I included all the buds whose lengths varied from 5 to $34 \mathrm{~mm}$. The shoot lengths of stages II and III varied from 35 to $100 \mathrm{~mm}$ and 110 to $250 \mathrm{~mm}$, respectively. Stage IV contained shoots which were longer than $250 \mathrm{~mm}$. The culture of shoot tips and the methods have already been described (Raju 1968; Ho 1970). For purposes of analyzing the apex, the median longisection was selected and divided into three sectors (Ho and Raju 1972). Figure 1 shows three sectors, the two peripheral $\left(\mathrm{S}_{1}\right.$ and $\left.\mathrm{S}_{3}\right)$ and the midsector $\left(\mathrm{S}_{2}\right)$.

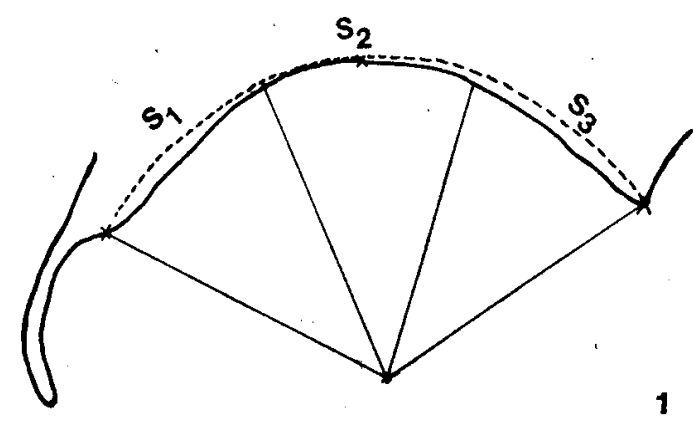

Fig. 1. Diagrammatic representation of a median longitudinal section of the shoot apex of leafy spurge showing the method for division of the apex into three equal sectors, two peripheral $\left(S_{1}\right.$ and $\left.S_{3}\right)$ and one mid-sector $\left(S_{2}\right)$.

\section{Histochemistry}

For purposes of histochemical studies, tips of buds and shoots were collected from greenhouse-grown plants and were fixed immediately in 10\% neutral formalin for 6 hours. The shoot tips were later dehydrated by graded $n$-butanol series (Johansen 1940) 
and embedded in paraplast for microtome sectioning. Longisections were made at $6 \mu \mathrm{m}$ thickness to study histochemical changes in the shoot apices.

The Feulgen method was used to study qualitatively the pattern of DNA distribution in the shoot apices, fixed in Carnoy's fluid. The sections were hydrolyzed in $1 \mathrm{~N} \mathrm{HCl}$ at $60^{\circ} \mathrm{C}$ for 10 minutes and stained for 1 hour in Schiff's reagent (Jensen 1962).

The qualitative identification of histones was made by following the method outlined by Alfert and Geschwind (1953). To determine the specificity of positive histone staining with fast green, the methods suggested by Swift (1964) were followed. There was no positive stain with fast green when DNA was not removed by hot trichloroacetic acid (TCA) or when sections were soaked in $0.2 \mathrm{~N} \mathrm{HCI}$ for 1 hour before staining. As cells contain heterogeneous histones and the main components histochemically identifiable are arginine-rich and lysine-rich histones, the acetylation procedure as outlined by Bloch and Hew $(1960 \mathrm{a}, \mathrm{b})$ was followed in some apices to block the lysine-rich histones and to allow the localization of arginine-rich histones.

The distribution of RNA in the apices was identified by the use of pyronin Y combined with methyl green, and the cytoplasmic basophilic material, RNA, stained red with pyronin Y. RNAse was used to determine the specificity of pyronin Y for RNA (Gude 1968). In no case did the sections treated with RNAse stain with pyronin $Y$.

\section{Histoautoradiography}

Tips of adventitious buds and shoots, $1 \mathrm{~cm}$ long, were isolated from greenhouse plants and cultured in small vials containing White's complete medium with $2 \%$ sucrose and $0.5 \%$ bacto-agar (White 1963). The techniques of isolating and culturing of shoot tips have been described earlier (Raju 1968; Ho 1970). The shoot tips were left for 72 hours in the culture room, which had a 12-hour photoperiod and day-night temperatures of $23 \pm$ $1^{\circ} \mathrm{C}$ and $20 \pm 1^{\circ} \mathrm{C}$, respectively. At the end of this period, tips were supplied with either thymidine- $\mathrm{H}^{3}$ or uridine- $\mathrm{H}^{3}$ with specific activities of 6.7 and 6.4 curies $/ \mathrm{m} M$, respectively, and each with a concentration of $0.5 \mu \mathrm{curies} / \mathrm{ml}$. Each vial received $0.8 \mathrm{ml}$ of radioactive solution (radioactive materials were from New England Nuclear, Boston). Three different feeding periods, of 48, 72, and 96 hours, were tried. The results given in Table 3 were obtained from apices treated for 72 and 96 hours. Table 4 contains results obtained from apices treated for 48 and 72 hours.

At the end of the experiment, the shoot tips were washed several times in distilled water and fixed in Carnoy's fluid for 8 hours. Dehydration was carried out in $n$-butanol series as mentioned earlier. The apices were cut to a thickness of $5 \mu \mathrm{m}$ for longisections.

The thymidine- $\mathrm{H}^{3}$ treated sections were stained with Feulgen reagent before emulsion was applied. The uridine- $\mathrm{H}^{3}$ treated sections were stained in a solution of pyronin $\mathrm{Y}$ and methyl green through the liquid emulsion film. Kodak $\mathrm{NTB}_{2}$ or $\mathrm{NTB}_{3}$ liquid emulsion was applied and the procedure outlined by Gude (1968) was followed to prepare slides for microscopic examination.

DNAse and RNAse (from Nutritional Biochemical Corporation, Cleveland, Ohio) were used to check the specificity of the labeling with radioactive tracers (Gude 1968). The enzyme digestions were carried out before staining and autoradiography. 


\section{Results}

\section{Histochemical studies}

The results of Feulgen stain are given in Table 1. Most shoot apices in stage I (Fig. 2 - next page) showed a slightly lighter zone in the center, but the difference in color intensity between the midsector $\left(S_{2}\right)$ and the peripheral sectors $\left(S_{1}\right.$ and $\left.S_{3}\right)$ was not very obvious. The remaining apices did not show any cytozonation at all. In stages II and III (Figs. $3,4)$ most of the apices showed a distinct lighter zone in the midsector, where the nuclei were large and rounded, showing less affinity for the stain. By contrast, the nuclei in the peripheral sectors were smaller with more dense stain. A sharp contrast in the intensity of stain between the midsector and the peripheral sectors was observed more frequently in stage III. The occurrence of such distal cells stained lightly with Feulgen has been reported in the shoot apices of Chenopodium album (Gifford and Tepper 1962a) and Helianthus annuus (Steeves et al. 1969) and in the apices of lateral inhibited buds of Tradescantia paludosa (Naylor 1958; Dwivedi and Naylor 1968). In leafy spurge, however, the zonal distribution of DNA that appeared characteristically in stages II and III disappeared in the apices of stage IV (Fig. 5). The intensity of Feulgen stain of the nuclei in $\mathrm{S}_{2}$ was as deep as of the nuclei in $\mathrm{S}_{1}$ and $\mathrm{S}_{3}$. Table 1 does indicate the existence of variation in each developmental stage. This variation is, however, expected because the classification used to recognize the four developmental stages is arbitrary.

Table 1 Distributional pattern of DNA in the shoot apex of Euphorbia esula L. at different stages.

\begin{tabular}{ccl}
\hline Stage & $\begin{array}{c}\text { No. of apices } \\
\text { observed }\end{array}$ & \multicolumn{1}{c}{ Pattern } \\
\hline I & 22 & $\mathrm{~S}_{2}$ stained slightly lighter than \\
& 10 & $\mathrm{~S}_{1}$, and $\mathrm{S}_{3}$ \\
II & 11 & $\mathrm{~S}_{1}, \mathrm{~S}_{2}$, and $\mathrm{S}_{3}$ stained uniformly \\
& 7 & $\mathrm{~S}_{2}$ stained lighter than $\mathrm{S}_{1}$ and $\mathrm{S}_{3}$ \\
III & 14 & $\mathrm{~S}_{1}, \mathrm{~S}_{2}$, and $\mathrm{S}_{3}$ stained uniformly \\
& 2 & $\mathrm{~S}_{2}$ stained lighter than $\mathrm{S}_{1}$ and $\mathrm{S}_{3}$ \\
IV & 3 & $\mathrm{~S}_{1}, \mathrm{~S}_{2}$, and $\mathrm{S}_{3}$ stained uniformly \\
& 20 & $\mathrm{~S}_{2}$ stained lighter than $\mathrm{S}_{1}$ and $\mathrm{S}_{3}$ \\
& & $\mathrm{~S}_{1}, \mathrm{~S}_{2}$, and $\mathrm{S}_{3}$ stained uniformly \\
\hline
\end{tabular}

Alkaline fast-green tests for histones in leafy spurge revealed that the distribution of nucleohistones was similar to that of Feulgen for DNA in all four stages of shoot development (Table 2; Figs. 6-11). 


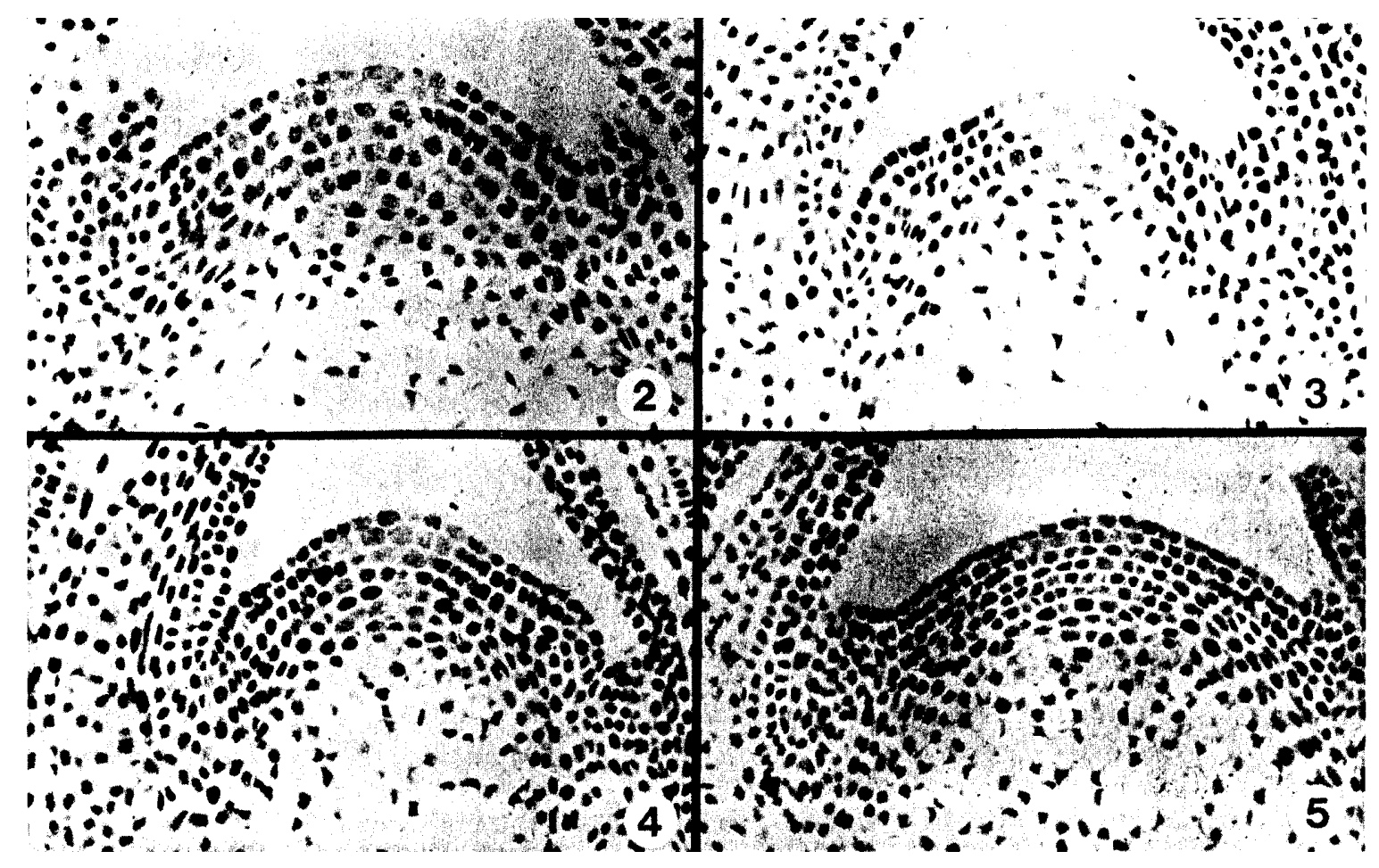

Fig. 2-5. Apices of four developmental stages of shoots of leafy spurge. Feulgen stained median longisections $(6 \mu \mathrm{m}$ thick). $\times 300$. Fig. 2 . Stage I. Midsector is stained only slightly. Zonal pattern is not very clear. Fig. 3. Stage II. Midsector is stained lighter than peripheral sectors. Fig. 4. Stage III. Midsector is stained lighter than peripheral sectors. Fig. 5. Stage IV. Entire apex is stained quite uniformly. Zonal pattern is not as obvious as in stages II and III.

Table 2. Distributional pattern of histones in the shoot apex of Euphorbia esula L. at different stages.

\begin{tabular}{ccc}
\hline Stage & $\begin{array}{c}\text { No. of apices } \\
\text { observed }\end{array}$ & \multicolumn{1}{c}{ Pattern } \\
\hline I & 13 & $\mathrm{~S}_{2}$ stained lighter than $\mathrm{S}_{1}$ and $\mathrm{S}_{3}$ \\
& 4 & $\mathrm{~S}_{1}, \mathrm{~S}_{2}$, and $\mathrm{S}_{3}$ stained uniformly \\
II & 10 & $\mathrm{~S}_{2}$ stained lighter than $\mathrm{S}_{1}$ and $\mathrm{S}_{3}$ \\
& 1 & $\mathrm{~S}_{1}, \mathrm{~S}_{2}$, and $\mathrm{S}_{3}$ stained uniformly \\
III & 11 & $\mathrm{~S}_{2}$ stained lighter than $\mathrm{S}_{1}$ and $\mathrm{S}_{3}$ \\
& 3 & $\mathrm{~S}_{1}, \mathrm{~S}_{2}$, and $\mathrm{S}_{3}$ stained uniformly \\
IV & 5 & Only a few nuclei in the center of \\
& & $\mathrm{S}_{2}$ stained slightly lighter than \\
& & the rest of the apex \\
& 8 & $\mathrm{~S}_{1}, \mathrm{~S}_{2}$, and $\mathrm{S}_{3}$ stained uniformly \\
\hline
\end{tabular}


In stages I to III (Figs. 6-9), most of the apices showed that in the midsector the nuclei stained very lightly with alkaline fast-green, while the nuclei in $\mathrm{S}^{1}$ and $\mathrm{S}^{3}$ were stained densely. It was difficult to recognize less densely stained nuclei in the $S^{2}$ of most apices of stage IV (Fig. 10). In some sections there were a few nuclei, four or five, which were round and large, located in the first and second mantle layers in the axial region; they were stained lighter than the rest of the nuclei in the apex.

The nucleoli were stained with alkaline fast-green in all apices, although less intensely in sector $S_{2}$ of stages I to III (Figs. 6-9). This is in contrast to the finding of Knox and Evans (1966), and Corson and Gifford (1969), who have reported that nucleoli appeared to be free of histones in the shoot apices of Lolium tomentum and Datura stramonium, respectively. Gifford and Dengler (1966) had earlier reported the occurrence of histones in the nucleoli in roots.

Figs. 6-8. Apices of leafy spurge at two different developmental stages of the shoot. Apices stained with alkaline fast-green for histones. Fig. 6. Stage I. Midsector is stained lighter than peripheral sectors. $\times 460$. Fig. 7 . Stage II. Midsector is stained lighter than peripheral sectors. Clear zonation is observed. $x$ 460. Fig. 8. Magnified picture of Fig. 3. Cytoplasm is stained with alkaline fast-green. In cells of the midsector the cytoplasm is stained denser than the nucleus. $\times 740$.

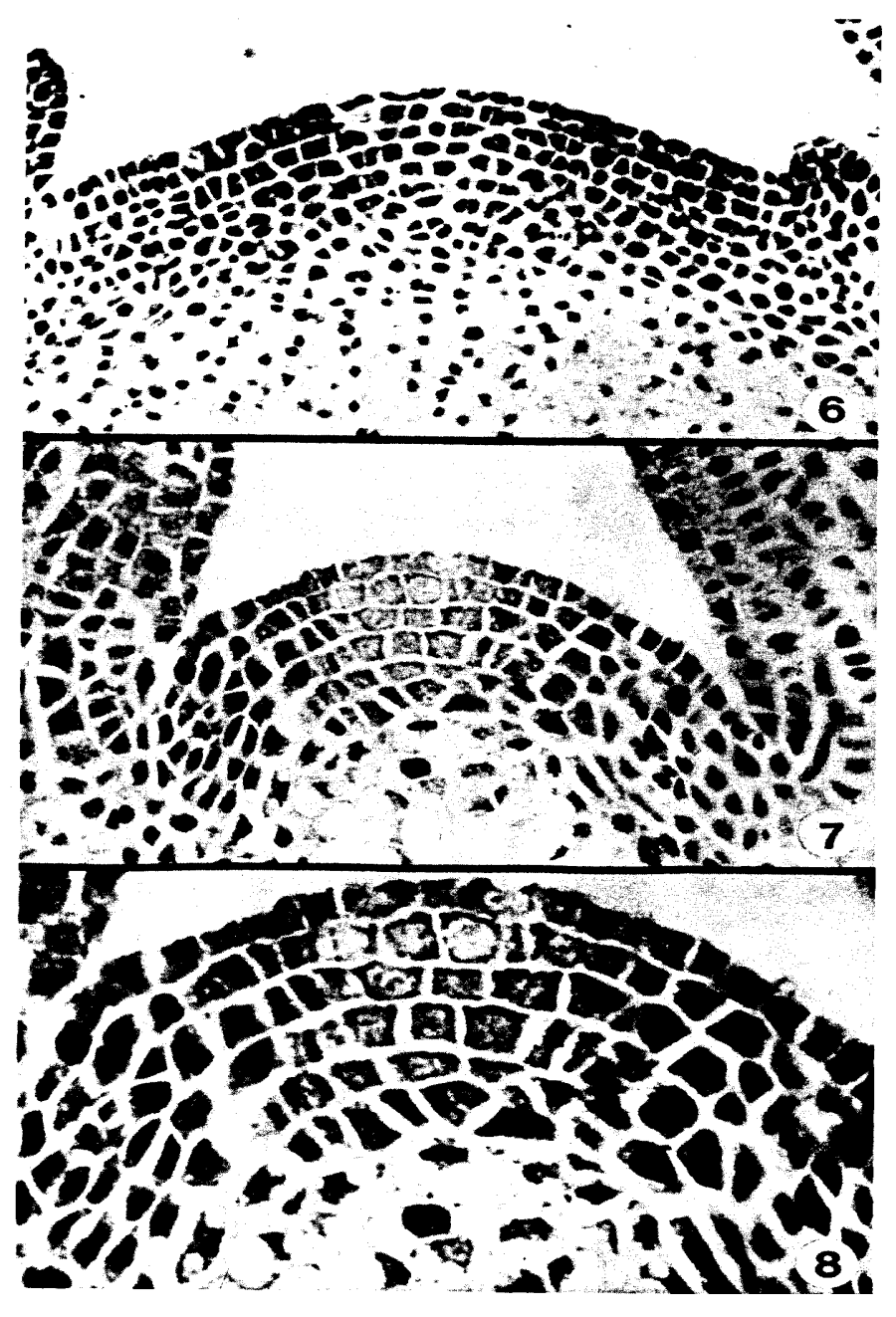


A positive basic fast-green staining in the cytoplasm of cells in the apex was observed in all cases. In stages I to III, the $\mathrm{S}_{2}$ region showed a greater intensity of staining with the dye in the cytoplasm than in the nucleus (Figs. 6-9). But in stage IV (Fig. 10), the nuclei were always stained darker than the cytoplasm in the entire apex.

As suggested by Bloch and Hew (1960a, b), 10 apices of leafy spurge were acetylated to block the staining of lysine-rich histories. The results indicated that in all four stages of development the apices were stained uniformly and suggested that the uniform staining of apex was due to arginine-rich histories (Fig. 11). The distribution of total histones, as revealed from alkaline fast-green method, was not even in apices of stages I to III, and became uniform in stage IV (Table 2). This change in the zonal pattern of histone distribution from the first three stages to stage IV would then be due to lysine-rich histories. A comparison of apices stained for histories with those of the acetylated apices showed similar intensity. Therefore, the major component of histories should be argininerich. More accurate measurements are, however, needed to confirm this conclusion.

Figs. 9-11. Apices of leafy spurge at two additional developmental stages of the shoot. Apices stained with alkaline fast-green for histones. Fig. 9. Stage III. Midsector stained lighter. Clear zonation in the apex is seen. $\times 460$. Fig. 10. Stage IV. Entire apex is stained uniformly. No zonation is observed. $x$ 460. Fig. 11. Acetylated shoot apex of stage II showing uniform staining with alkaline fast-green. $x$ 406.

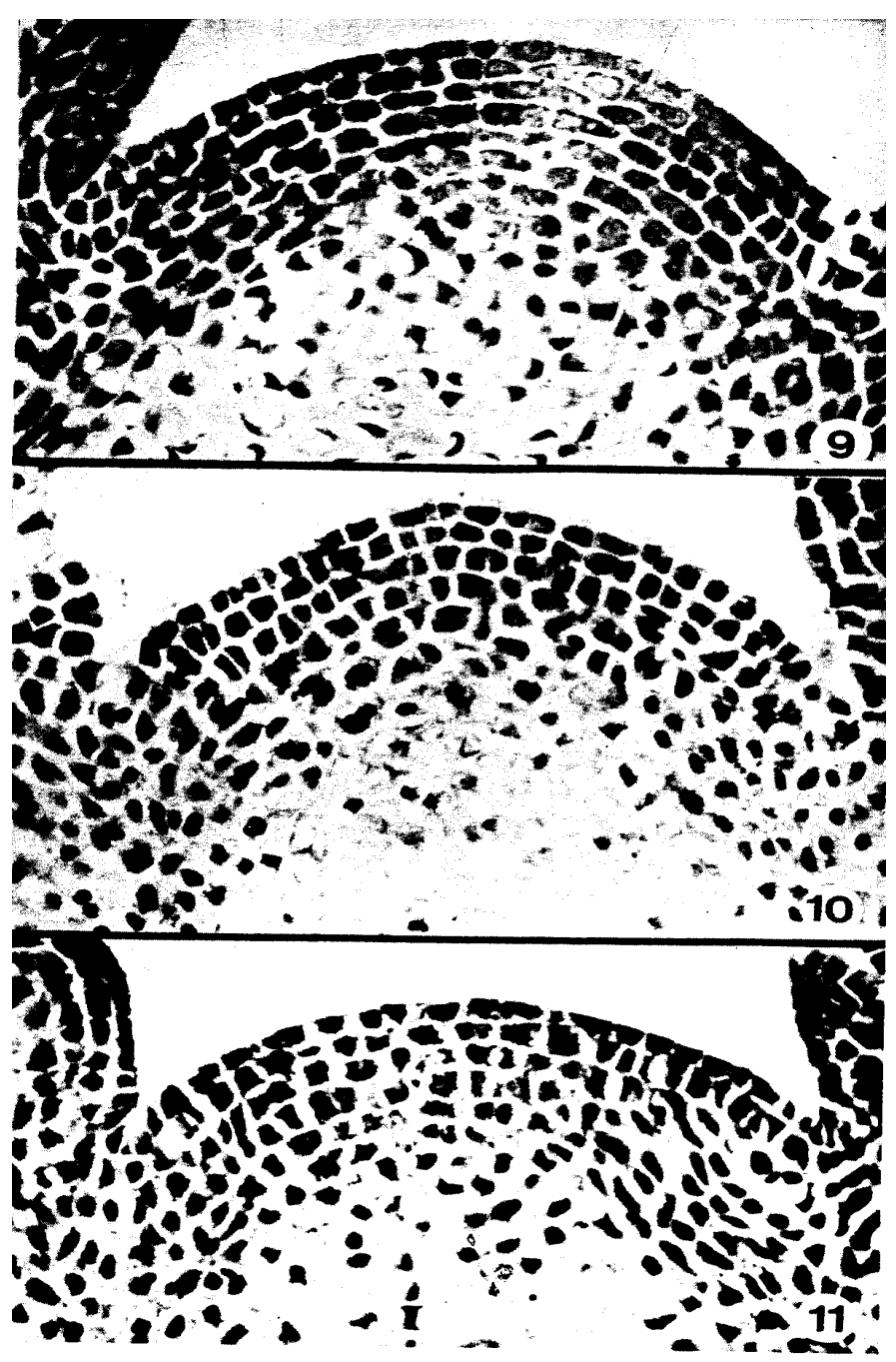


The pyronin $\mathrm{Y}$ and methyl green staining procedure indicated a uniform distribution of high RNA content in the cytoplasm of cells in the apex. In all the 48 shoot apices selected from stages I to IV, no distinct lighter central zone was found (Figs. 12-15). In some instances, where the apex contained initials of leaf primordia, the peripheral sectors were more dense in cytoplasmic RNA than the middle one. Like the cytoplasm, the nucleoli in the apex were bright red, indicating the presence of RNA. An attempt was made to determine if there was any change in RNA concentration in different stages of development of the apex. Apices from various developmental stages, which were collected on the same day, were stained together to minimize the variation. The color intensity by visual observation of the slides showed no obvious change at different developmental stages. Therefore, the cytoplasmic RNA was quite uniformly distributed in cells of the vegetative shoot apex.

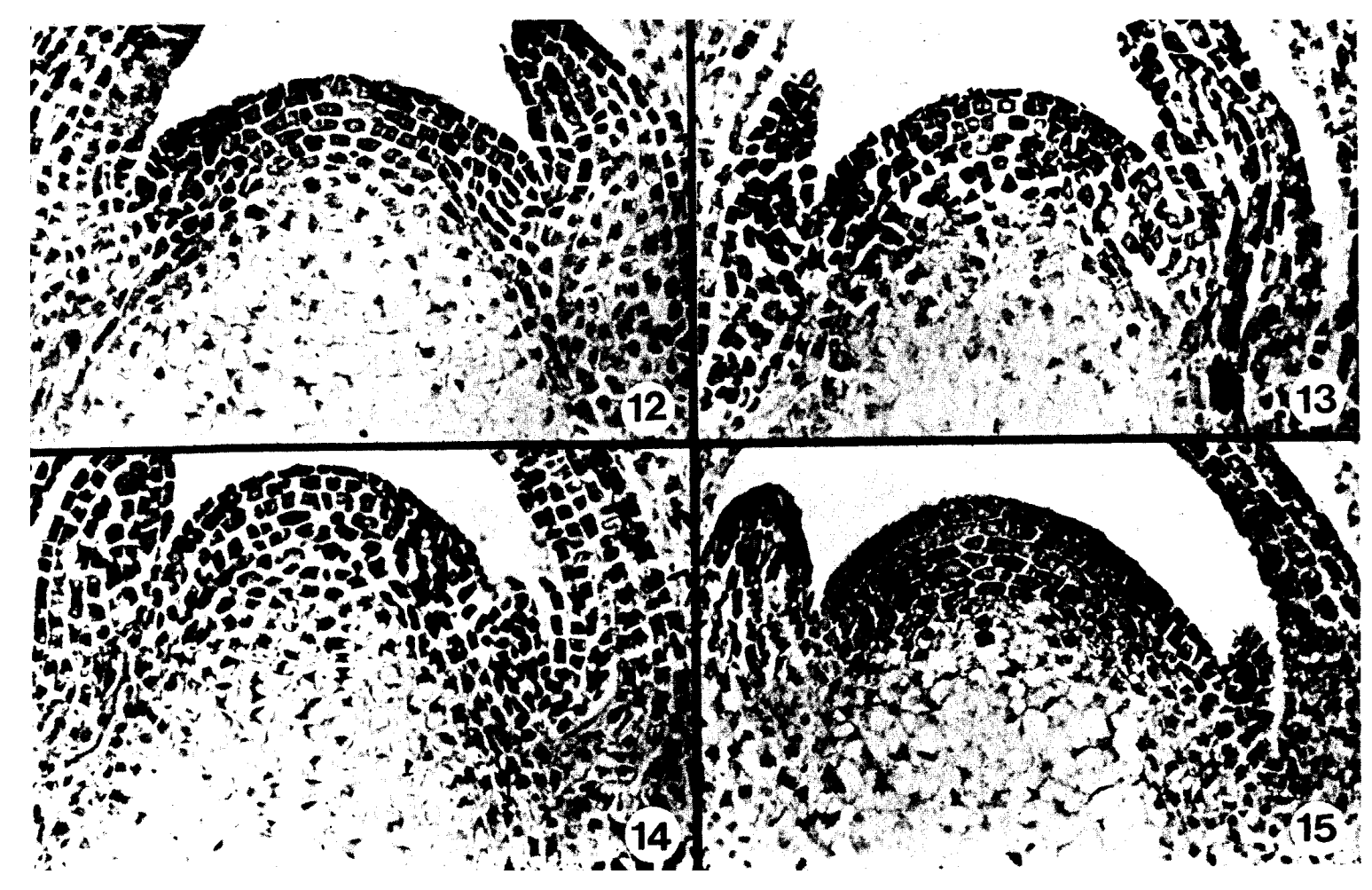

Figs. 12-15. Shoot apices of leafy spurge at four developmental stages. Apices are stained with pyronin $Y$ and methyl green. Cytoplasmic RNA staining is uniform in stages I-IV. $\times$ 460.

\section{Autoradiographic studies}

Only longitudinal sections were used here to analyze the leafy spurge shoot apices. The number of silver grains over the cut nucleus or cytoplasm in each cell was counted. In some instances the grains per nucleus were so numerous that no accurate grain counts exceeding 30 per nucleus were made. The silver grains that were seen in the blank slides 
with emulsion only and in the areas between sections were considered as background radiation, which in both cases was comparable. The method suggested by Steeves et al. (1969) was followed to determine the background radiation.

Of the 110 apices of adventitious buds and shoots treated with thymidine- $\mathrm{H}^{3}$, only 36 exposed for 48, 72, and 96 hours were processed and analyzed in detail. A summary of the incorporation of thymidine- $\mathrm{H}^{3}$ in four stages is given in Table 3 . In stage $\mathrm{I}$, the rate of incorporation of labeled compound, as determined by the number of grains in the apex, was lower than in the other three stages. There were, however, a slightly higher number of silver grains per nucleus in the peripheral sectors $\left(S_{1}\right.$ and $\left.S_{3}\right)$ than in $S_{2}$ (Fig. 16); but the mean differences were not significant at the $95 \%$ confidence interval when they were analyzed by $t$-test. In stages II and III, the amount of thymidine- $\mathrm{H}^{3}$ taken up per nucleus in $S_{2}$ was about half that taken up in $S_{1}$ or $S_{3}$. Heavily labeled nuclei appeared very frequently in the peripheral region in stages II and III (Figs. 17, 18), and, by contrast, the nuclei with abundant silver grains were not common in the midsectors of the corresponding stages. The differences of mean counts per nucleus between peripheral sectors and the midsector were significant at the 95\% level in stages II and III. In stage IV (Fig. 19), silver grains were uniformly distributed in all the three sectors. Their mean counts per nucleus in $\mathrm{S}_{1}, \mathrm{~S}_{2}$, and $\mathrm{S}_{3}$ were similar and the differences between the means were not significant at the $95 \%$ level.

Table 3. A summary of results of incorporation of thymidine- $\mathrm{H}^{3}$ in the shoot apex of $E$ phorbia esula $\mathrm{L}$.

\begin{tabular}{lcc}
\hline Stage & Sector & $\begin{array}{c}\text { Net grains per nucleus, } \\
\text { mean } \pm \text { S.E. }\end{array}$ \\
\hline I & $\mathrm{S}_{1}$ & $3.352 \pm 0.593$ \\
$(6)^{*}$ & $\mathrm{~S}_{2}$ & $2.394 \pm 0.571$ \\
& $\mathrm{~S}_{3}$ & $2.954 \pm 0.476$ \\
II & & \\
$(10)$ & $\mathrm{S}_{1}$ & $6.608 \pm 1.009$ \\
& $\mathrm{~S}_{2}$ & $3.350 \pm 0.768$ \\
& $\mathrm{~S}_{3}$ & $6.462 \pm 0.861$ \\
III & & \\
$(10)$ & $\mathrm{S}_{1}$ & $7.746 \pm 1.051$ \\
& $\mathrm{~S}_{2}$ & $3.556 \pm 0.649$ \\
IV & $\mathrm{S}_{3}$ & $7.891 \pm 0.903$ \\
$(10)$ & & \\
& $\mathrm{S}_{1}$ & $6.069 \pm 0.818$ \\
& $\mathrm{~S}_{2}$ & $5.131 \pm 0.741$ \\
& $\mathrm{~S}_{3}$ & $5.885 \pm 1.054$ \\
\hline
\end{tabular}

*Sample size. 


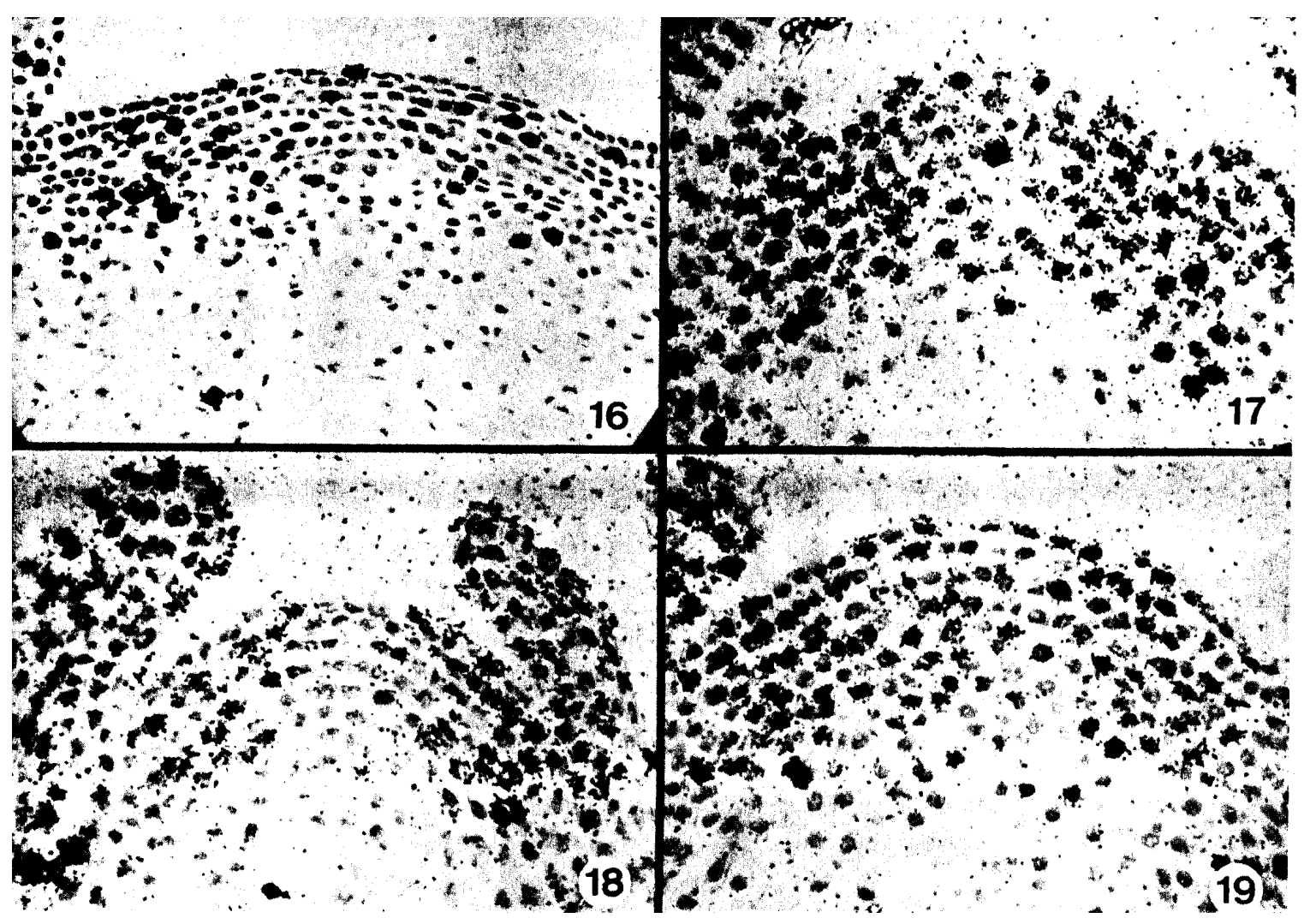

Fig. 16-19. Histoautoradiographs of median longisections of shoot apices of leafy spurge (Feulgen stained sections $5 \mu \mathrm{m}$ thick.). $\times$ 450. Fig. 16. Stage I. Fed for 72 hours with thymidine-H ${ }^{3}$. Fig. 17. Stage II. Fed for 72 hours with thymidine-H ${ }^{3}$. Fig. 18. Stage III. Fed for 48 hours with thymidine-H ${ }^{3}$. Fig.19. Stage IV. Fed for 72 hours with thymidine-H ${ }^{3}$.

Table 4. A summary of results of incorporation of uridine- $\mathrm{H}^{3}$ in the shoot apex of Euphorbia esula L.

\begin{tabular}{lcccc}
\hline & $\begin{array}{c}\text { Net grains } \\
\text { per cytoplasm, } \\
\text { mean } \pm \text { S.E. }\end{array}$ & $\begin{array}{c}\text { Net grains } \\
\text { per nucleus, } \\
\text { mean } \pm \text { S.E. }\end{array}$ & $\begin{array}{c}\text { Net grains } \\
\text { per cell, } \\
\text { mean } \pm \text { S.E. }\end{array}$ \\
\hline Stage & Sector & $4.203 \pm 0.202$ & $3.385 \pm 1.285$ & $7.588 \pm 1.489$ \\
$(2)^{*}$ & $\mathrm{~S}_{1}$ & $3.967 \pm 1.608$ & $3.125 \pm 0.847$ & $7.092 \pm 2.456$ \\
& $\mathrm{~S}_{2}$ & $4.344 \pm 1.037$ & $3.527 \pm 0.973$ & $7.872 \pm 2.010$ \\
II & $\mathrm{S}_{3}$ & & & \\
$(7)$ & & & $7.537 \pm 0.647$ & $15.895 \pm 1.271$ \\
& $\mathrm{~S}_{1}$ & $8.357 \pm 0.829$ & $6.828 \pm 0.473$ & $14.573 \pm 0.871$ \\
III & $\mathrm{S}_{2}$ & $7.745 \pm 0.714$ & & $14.595 \pm 0.913$ \\
$(6)$ & $\mathrm{S}_{3}$ & $7.452 \pm 0.554$ & & \\
& & & & \\
& $\mathrm{~S}_{1}$ & $12.370 \pm 1.379$ & $8.444 \pm 1.030$ & $20.815 \pm 2.260$ \\
IV & $\mathrm{S}_{2}$ & $12.270 \pm 1.961$ & $7.862 \pm 1.367$ & $21.133 \pm 3.272$ \\
$(5)$ & $\mathrm{S}_{3}$ & $10.643 \pm 1.424$ & & $18.345 \pm 2.964$ \\
& & & & \\
& $\mathrm{~S}_{1}$ & $8.648 \pm 0.604$ & $7.034 \pm 0.646$ & $15.682 \pm 1.149$ \\
& $\mathrm{~S}_{2}$ & $8.336 \pm 0.591$ & $6.280 \pm 1.136$ & $14.617 \pm 1.727$ \\
& $\mathrm{~S}_{3}$ & $8.143 \pm 0.658$ & $6.919 \pm 0.872$ & $15.062 \pm 1.387$ \\
\hline
\end{tabular}

*Sample size 
The specificity of the labeling with DNA precursor, thymidine- $\mathrm{H}^{3}$, was further verified by DNAse digestion method (Gude 1968); no silver grains of any significance were present over the nuclei.

Of the 48 shoot apices treated with uridine- $\mathrm{H}^{3}$ for 48 and 72 hours, 20 apices were analyzed for RNA. Grain counts were made in the cytoplasm and in the cut nuclei in each of the three sectors in four different developmental stages. A summary of grain counts per nucleus and for the whole cytoplasm is given in Table 4. The distribution of grains was uniform in all the sectors of the apex and in all the four stages (Figs. 20-23). All $t$ test values indicate that the differences between the mean number of grains per cell of $S_{1}$, $\mathrm{S}_{2}$, and $\mathrm{S}_{3}$ were not significant at the $95 \%$ level in all four stages.

As expected, there was an increase in the number of silver grains in the cytoplasm with longer feeding period. In the apices that were exposed to uridine- $\mathrm{H}^{3}$ for 48 hours the number of grains in the cytoplasm and in the nucleus was about the same. In some apices more grains were found in the nuclei than in the cytoplasm. Most of the apices which were treated with uridine $-\mathrm{H}^{3}$ for 72 hours had denser labeling in the cytoplasm than in the nuclei.

RNAse was used to test the specificity of uridine- $\mathrm{H}^{3}$ for RNA (Gude 1968). No silver grains could be seen in the emulsion over the cell when uridine- $\mathrm{H}^{3}$ treated sections were digested with RNAse.

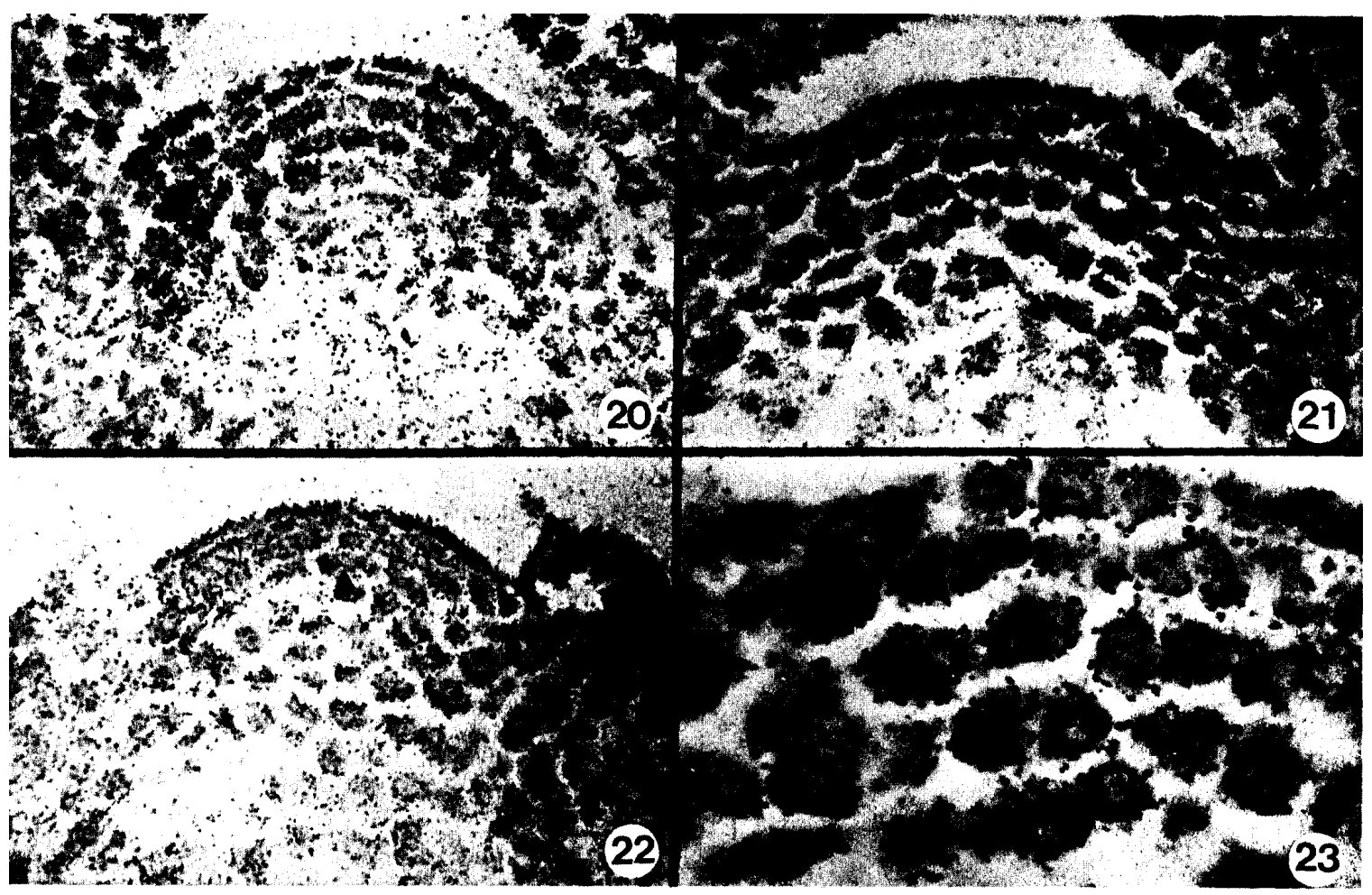

Figs. 20-23. Histoautoradiographs of median longisections of shoot apices of leafy spurge stained with pyronin $Y$ and methyl green (sections $5 \mu \mathrm{m}$ thick). $\times 450$. Fig. 20. Stage II. Fed

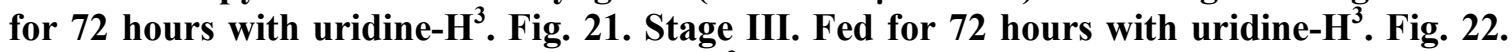
Stage IV. Fed for 48 hours with uridine- $\mathrm{H}^{3}$. Fig. 23. Part of apex in Fig. 17 magnified to show silver grains over nuclei and cytoplasm. $\times 900$. 


\section{Discussion}

The results of the present histochemical and histoautoradiographic studies no doubt indicate the presence of a cytozonation which in a way is comparable to that obtained earlier from routine histological studies of the apices of adventitious shoots of leafy spurge (Raju 1968; Ho and Raju 1972). Such a zonal pattern in many instances has been reported to be greatly accentuated by the conspicuous central zone, in which there is little or no mitotic activity (Nougarède 1967; Gifford and Corson 1971). The structural and functional aspects of this central zone have been debated and have recently been discussed very succinctly (Steeves et al. 1969; Gifford and Corson 1971). Although the central zone has been identified in apices belonging to a wide variety of angiosperms, still its universal occurrence in plants has not been agreed upon (see Gifford 1954; Clowes 1961; Gifford and Corson 1971). This lack of agreement is further compounded by the application of a variety of techniques such as histochemical, histoautoradiographic, physiological, etc. More important than these is the stage of shoot development, which appears to be correlated with the presence and extent of a central zone in the apex. Evidence from several sources suggests the presence of a quiescent center in the shoot apex during active vegetative growth in many angiosperms (Gifford 1954; Steeves et al. 1969; Gifford and Corson 1971).

In leafy spurge the DNA distribution and also DNA synthesis, based on the results obtained from the usual techniques such as Feulgen staining and thymidine- $\mathrm{H}^{3}$ treatment, showed a similar pattern in the apices of adventitious shoots. In stage I of shoot development the nuclei in the midsector were less densely stained than those of the peripheral sectors. In stages II and III an unmistakable lighter zone was observed in the midsector. As no microspectrophotometric analysis was carried out, it is not clear whether the lighter zone seen was due to low DNA content in the nuclei or a case of dilution effect because of the larger nuclei.

It has been shown earlier that cells in mitosis occurred more frequently in the peripheral sectors than in the midsector of the apices in leafy spurge (Raju 1968). It is reasonable to assume, therefore, that the DNA staining pattern obtained is an indication of mitotic activity. In stages II and III the Feulgen stain in the nuclei is darker in $\mathrm{S}_{1}$ and $\mathrm{S}_{3}$, than in those in $S_{2}$, reflecting greater mitotic activity in the periphery. This can also be correlated with the fact that there is rapid initiation of leaf primordia during the vegetative phase. In stage I, by contrast, the leaf production is very slow and consequently there is less mitotic activity in the periphery; the zonal pattern is less marked.

The zonal pattern or cytozonation observed earlier disappeared in stage IV, as evidenced by the uniform distribution of Feulgen stain and thymidine- $\mathrm{H}^{3}$ incorporation. Similar change has also been reported during the transformation of vegetative apex to floral state in Chenopodium album (Gifford and Tepper 1962a) and Helianthus annuus (Steeves et al. 1969). Since the adventitious shoots of leafy spurge do not generally flower under conditions in which the plants were raised (Ho and Raju 1972), the disappearance of cytozonation in the apex in stage IV may represent the "intermediate phase" (Nougarède 1967). Changes in the cytozonation in different developmental stages indicate the possible difference in the rate of DNA synthesis. A similar observation has also

Page 13 of 17 
been reported for Coleus blumei, which is a quantitative long-day plant (Saint-Côme 1966). When its shoot apex was treated with thymidine- $\mathrm{H}^{3}$ for 6 hours and grown under short days, the number of labeled nuclei increased significantly in the axial zone.

It has been reported that during the vegetative phase the mitotic activity or the rate of DNA synthesis is lower in the distal central zone in many plants, corresponding to the concept of méristème d'attente (Lance 1952, 1957; Gifford et al. 1963). The midsector $\left(\mathrm{S}_{2}\right)$ in leafy spurge cannot, however, be regarded as méristème d'attente. As mentioned earlier, the reason for the lighter Feulgen stain in the nuclei of the midsector is not at present exactly known. The nuclei might be in $2 \mathrm{C}$ or $4 \mathrm{C}$ condition. Some nuclei in $\mathrm{S}_{2}$ sector are apparently synthesizing DNA, as indicated by the presence of silver grains on them. So, the reason for the nuclei of $\mathrm{S}_{2}$ having less DNA, indicated by stain, and a slower rate of DNA synthesis in the active vegetative phase (stages II and III) of the shoot apex, is probably due to long mitotic cycle. If this interpretation is correct, then the nuclei in the central region $\left(\mathrm{S}_{2}\right)$ will have a longer duration in $\mathrm{G}_{1}(2 \mathrm{C})$ or $\mathrm{S}$ or $\mathrm{G}_{2}(4 \mathrm{C})$. This can only be confirmed by spectrophotometric measurements.

The distribution of nucleohistones in the apices of adventitious shoots of leafy spurge follows the DNA pattern. As in DNA pattern, the histones increased considerably in stage IV. Gifford and Tepper $(1962 \mathrm{a}, \mathrm{b})$ have reported that the histone content decreased during later stages of inflorescence development. Knox and Evans (1966) have, on the other hand, reported that the histone distribution in Lolium temulentum shoot apices was similar to DNA at all stages of floral induction.

The acetylated shoot apices showed that the arginine-rich histone fraction was dominant and also uniform in all four stages of development. Therefore, in stages II and III, in which the synthesis of DNA was rapid in the periphery, the sectors, $S_{1}$ and $S_{3}$, had more lysine-rich histones than did the midsector, $\mathrm{S}_{2}$. In stage IV the same lysine-rich histones increased in the midsector, which showed an increase in DNA synthesis. It seems, therefore, that there is a correlation between lysine-rich histones and DNA synthesis. During the rapid vegetative growth phase, stages II and III, the distal central region has a longer mitotic cycle (slow DNA synthesis), which may be due to less lysine-rich histone content. When the apex gradually grows into the intermediate phase (stage IV), some cytochemical and structural changes occur in it; this would probably lead to a slow preparation for flowering. The lysine-rich histone content increases in the interphase nuclei of $\mathrm{S}_{2}$ in stage IV. It has also been reported that the lysine-rich histones are responsible for condensed chromatin in the interphase nuclei of calf thymus lymphocytes as well as in the metaphase chromosomes of HeLa cells (Littau et al. 1965; Mirsky et al. 1968, Hearst and Botchan 1970). A particular role of histones in dividing cells has also been suggested for bud apices of Tradescantia paludosa by Dwivedi and Naylor (1968).

More lysine-rich histones in the peripheral sectors in the vegetative phase (stages II and III) and later in the central region of the apex in the intermediate phase (stage IV) in leafy spurge may have some role in histogenesis or organogenesis in the shoot apex. An analogous situation, wherein the fractions of histones are known to control early embryogenesis of sea urchin, has been reported (Vorobeyev et al. 1969). However, more detailed study on leafy spurge shoot apices needs to be done.

Page 14 of 17 
The cytoplasm in the shoot apices of leafy spurge was stained with alkaline fast-green in all cases during this study. In stages II and III, almost all apices showed that the cytoplasm had more stain than the nuclei in the midsector, but in stage IV, the cytoplasm contained less stain than the nuclei in the same region. Recently, Corson and Gifford (1969) have reported that the intensity of basic fast-green stain in the cytoplasm in the shoot apex of Datura stramonium increased at flowering.

In leafy spurge shoot apices, the cytoplasm was more densely stained with alkaline fast-green than the nucleus in the distal central region $\left(\mathrm{S}_{2}\right)$ during the rapid growth phase (stage II and III). In the same region the nuclei were observed to have slow DNA synthesis. Considering the above facts, it might be suggested that if histones were, in fact, synthesized in cytoplasm during $\mathrm{G}_{1}$ or $\mathrm{S}$ and bound to the chromatin in the mitotic phase, as reported in HeLa cells (Robbins and Borun 1967), one would then expect more histones in the cytoplasm of cells where the nucleus would show a prolonged mitotic cycle.

Table 4 shows no sharp difference in RNA distribution between sectors of the apex in all the four stages of shoot development. In the rapid growth phase (stage II and III) the central region was less active in DNA synthesis; the RNA synthesis in that region was, however, similar to that in the peripheral sectors. The uniformity of cytoplasmic RNA distribution and synthesis in the shoot apex suggests that the distal central region $\left(\mathrm{S}_{2}\right)$ is quite active metabolically throughout development of the shoot. These results are not in agreement with the results reported for other plants in which the cytozonation of RNA has been observed (Lance 1954, 1957; Gifford and Tepper 1962a, b). Corson and Gifford (1969) have shown that the axial cells during vegetative and transitional phases contained less RNA than those in the peripheral zones.

There is much evidence to support the idea that RNA synthesis can occur independently of DNA synthesis (Killander et al. 1962; Caspersson et al. 1963). Caspersson et al. (1965) have shown that when murine cells were exposed to 5-fluorodeoxyuridine ribose, a DNA synthesis inhibitor, DNA synthesis stopped and no cells passed from $G_{1}$ to $S$ and $\mathrm{G}_{2}$ phases. In stages II and III of the shoot apices of leafy spurge, RNA synthesis was present in the midsector $\left(\mathrm{S}_{2}\right)$ even though there was little or no DNA synthesis in the nuclei.

\section{Acknowledgments}

We thank Professor G. F. Ledingham for reading the manuscript. Grateful acknowledgment is made of financial support from the National Research Council of Canada.

\section{Literature cited}

Alfert, M. and J. J. Geschwind. 1953. A selective staining method for the basic proteins of cell nuclei. Proc. Natl. Acad. Sci. U.S.A. 39:991-999.

Bernier, G. 1970. Cellular and molecular aspects of floral induction. Longman Group Ltd., London.

Bloch, D. P. and H. Y. Hew. 1960a. Schedule of spermatogenesis in pulmonate snail Helix aspersa, with special reference to histone transition. J. Biophys. Biochem. Cytol. 7:515-530.

Page 15 of 17 
Bloch, D. P. and H. Y. Hew. 1960b. Changes in nuclear histones during fertilization and early embryonic development in the pulmonate snail, Helix aspersa. J. Biophys. Biochem. Cytol. 8:69-81.

Buvat, R. 1952. Structure, évolution et fonctionnement du méristème apical de quelques dicotylédones. Ann. Sci. Nat. Bot. Biol. Veg. 13:199-300.

Buvat, R. 1953. L'apex de Triticum vulgare; modalités de reprises des mitoses lors de la germination et du fonctionnement végétatif. C.R. Hebd. Séances Acad. Sci. Ser. D, Sci. Nat. (Paris), 236:1989-1991.

Caspersson, T., S. Farber, G. E. Foley, and D. Killander. 1963. Cytochemical observations on the nucleolus-ribosome system. Exp. Cell Res. 32:529-552.

Caspersson, T., S. Farber, G. E. Foley, D. Killander, and A. Zetterberg. 1965. Cytochemical evaluation of metabolic inhibitors in cell culture. Exp. Cell Res. 39:365-385.

Clowes, F. A. L. 1961. Apical meristems. Blackwell Sci. Publ., Oxford.

Corson, G. E. and E. M. Gifford. 1969. Histochemical studies of the shoot apex of Datura stramonium during transition to flowering. Phytomorphology (Delhi), 19:189-196.

Dwivedi, R. S. and J. M. Naylor. 1968. Influence of apical dominance on the nuclear proteins in cells of the lateral bud meristem in Tradescantia paludosa. Can. J. Bot. 46:289-298.

Gifford, E. M. 1954. The shoot apex in angiosperms. Bot. Rev. 20:477-529.

Gifford, E. M. and G. E. Corson. 1971. The shoot apex in seed plants. Bot. Rev. 37:143-229.

Gifford, E. M. and H. B. Tepper. 1962a. Histochemical and autoradiographic studies of floral induction in Chenopodium album. Am. J. Bot. 49:706-714.

Gifford, E. M. and H. B. Tepper. 1962b. Ontogenetic and histochemical changes in the vegetative shoot tip of Chenopodium album. Am. J. Bot. 49:902-911.

Gifford, E. M. and R. E. Dengler. 1966. Histones and alkaline fast green staining of onion roots. Am. J. Bot. 53:1125-1132.

Gifford, E. M., S. Kupila, and S. Yamaguci. 1963. Experiments in the application of $\mathrm{H}^{3}$-thymidine and adenine-8- $\mathrm{C}^{14}$ to shoot tips. Phytomorphology (Delhi), 13:14-22.

Gude, W. D. 1968. Autoradiographic techniques. Localization of radioisotopes in biological material. Prentice-Hall, Inc., Englewood Cliffs, N.J.

Hearst, J. E. and M. Botchan. 1970. The Eukaryotic chromosome. Annu. Rev. Biochem. 39:151-182.

Heslop-Harrison, J. and Y. Heslop-Harrison. 1970. The state of the apex and the response to induction in "Cannabis sativa." In Cellular and molecular aspects of floral induction. Edited by G. Bernier. Longman Group Ltd., London. pp. 3-26.

Ho, T. W. M. 1970. Histological and cytochemical studies of the adventitious shoot apices of leafy spurge (Euphorbia esula L.). M.Sc. Thesis, University of Saskatchewan, Regina, Sask.

Ho, T. W. M. and M. V. S. Raju. 1972. Developmental studies on leafy spurge (Euphorbia esula L.). Histology of the adventitious shoot apex. Can. J. Bot. 50:635-641.

Jensen, W. A. 1962. Botanical histochemistry. W. H. Freeman and Co., San Francisco.

Johansen, D. A. 1940. Plant microtechnique. McGraw-Hill, N.Y.

Killander, D., B. M. Richards, and N. R. Ringertz. 1962. The effect of x-radiation on nuclear nucleotide content as studied by ultraviolet-microspectrophotometry on tumor cells. Exp. Cell Res. 27:321-375.

Knox, R. B. and L. T. Evans. 1966. Inflorescence initiation in Lolium temulentum L. Histochemical changes at the shoot apex during induction. Aust. J. Blot. Sci. 19:233-245.

Lance, A. 1952. Sur la structure et le fonctionnement du point végátatif de Vicia faba. Ann. Sci. Nat. Bot. Biol. Veg. Ser. 2, 13:301-339. 
Lance, A. 1953a. Sur l'absence d'initiales apicales et la configuration de l'anneau initial chez Vicia faba. C.R. Hebd. Séances Acad. Sci. Ser. D, Sci. Nat. (Paris), 236:510-512.

Lance, A. 1953b. Sur la variation nycthémérale de l'activité mitotique dans; l'apex de Vicia faba. C.R. Hebd. Séances Acad. Sci. Ser. D, Sci. Nat. (Paris), 236:844-846.

Lance, A. 1954. Evolution histologique de l'apex d'Aster sinensis. C.R. Hebd. Séances Acad. Sci. Ser. D, Sci. Nat. (Paris), 238:1442-1444.

Lance, A. 1957. Recherches cytologiques sur l'évolution de quelques méristémes apicaux et sur ses variations provoquées par des traitements photopériodiques. Ann. Sci. Nat. Bot. Biol. Veg. Ser. 2, 18:91421.

Littau, V. C., C. J. Burdick, V. G. Allfrey, and A. E. Mirsky. 1965. The role of histones in the maintenance of chromatin structure. Proc. Natl. Acad. Sci. U.S.A. 54:1204-1212.

Mirsky, A. E., C. J. Burdick, E. H. Davidson, and V. C. Littau. 1968. The role of lysine-rich histone in the maintenance of chromatin structure in metaphase chromosomes. Proc. Natl. Acad. Sci. U.S.A. 61:592597.

Naylor, J. M. 1958. Control of nuclear processes by auxin in axillary buds of Tradescantia paludosa. Can. J. Bot. 36:221-232.

Nougarède, A. 1967. Experimental cytology of the shoot apical cells during vegetative growth and flowering. Int. Rev. Cytol. 21:203-351.

Nougarède, A., and R. Bronchart. 1965. Le métabolisme des acides nucléiques au cours des diverses phases du devéloppement dans le méristème du Perilla nankinensis. Bull. Soc. Fr. Physiol. Veg. 11:149-154.

Raju, M. V. S. 1968. Developmental studies on leafy spurge (Euphorbia esula). Apices of seedling and adventitious shoots. Can. J. Bot. 46:1529-1532.

Raju, M. V. S., T. A. Steeves, and R. T. Coupland. 1963. Developmental studies on Euphorbia esula L. Morphology of the root system. Can. J. Bot. 41:579-589.

Raju, M. V. S., T. A. Steeves, and R. T. Coupland. 1964. On the regeneration of root fragments of leafy spurge (Euphorbia esula L.). Weed Res. 4:2-11.

Robbins, E. and T. W. Borun. 1967. The cytoplasmic synthesis of histones; in HeLa cells and its temporal relationship to DNA replication. Proc. Natl. Acad. Sci. U.S.A. 57:409-416.

Saint-Côme, R. 1966. Application des techniques histoautoradiographiques et des méthodes statistiques à 1'étude du fonctionnement apical chez le Coleus blumei Benth. Rev. Gen. Bot. 73:241-323.

Steeves, T. A., M. A. Hicks, J. M. Naylor, and P. Rennie. 1969. Analytical studies on the shoot apex of Helianthus annuus. Can. J. Bot. 47:1367-1375.

Swift, H. 1964. The histones of polytene chromosomes. In The nucleohistones. Edited by J. Bonner and P. T’so. Holden-Day Inc., San Francisco. pp. 169-183.

Vorobeyev, V. I, A. A. Gineitis, and I. A. Vinogradova. 1969. Histones in early embryogenesis. Exp. Cell. Res. 57:1-7.

White, P. R. 1963. The cultivation of animal and plant cells. 2nd ed. Ronald Press, New York. 